\title{
A Preliminary Analysis of Spatial Trajectories of Residential Migration in Pretoria, South Africa
}

\author{
Kazuko TANAKA \\ Department of Regional Environment Studies, Fukui University, \\ Bunkyo, Fukui 910-8507, Japan
}

\begin{abstract}
A migration career, that is, a trajectory of personal migrations in space and time, is an important element in the understanding of urban residential areas. From this perspective, this paper analyzes and describes patterns of migration careers for South African people in Pretoria, South Africa. Pretoria was chosen as the study area because, in contrast with American cities, it is a city with less freedom. Sampled subjects were taken from groups of upper-class Whites, lower-class Whites and non-Whites. As for migration frequencies and motivations, there are clear differences not only between Whites and non-Whites, but also between upper-class and lower-class Whites. Each group shows a distinctive pattern of trajectories of residential shifts within Pretoria. Whites are characterized by much higher mobility than non-Whites. Their motivations and spatial trajectories are influenced by (1) the political oppression of apartheid, (2) economical affordability; and (3) a strong ethnical sense of belonging to their own communities. Spatial trajectories of South African migration careers are different from American ones. Both Whites and non-Whites in South Africa shift their residences within urban areas defined by the racial segregation imposed by apartheid. Americans move according to their preference of a place to live. This difference is derived from different urban histories; people and their lives are also different between the two societies. It should be noted that there is a strong interaction between people's urban lifestyle and the urban spatial structure. Residential differentiation is an important theme in the analysis of urban structures. Studies of migration careers in urban space are expected to give answers to fundamental questions regarding residential differentiation.
\end{abstract}

Key words: migration career, spatial trajectory, segregation, American migration, South Africa, Pretoria

\section{Introduction}

People migrate throughout their lives due to many different motivations, including education, marriage, divorce, work, childbirth, and retirement. People tend to move several times even within a single city or town. Also, in urban factorial ecology, progress of the family status/life-cycle, which is one of the major dimensions of urban society, has been recognized as related to zonal patterns in urban space (Knox 1987: 130). This means that cities provide a variety of residential districts and housing types, from which people can choose their places of residence and styles of home. It is expected that a clear relation exists between the spatial trajectories of personal residential shifts and the locations of various residential districts within a city. Based on this assumption, this paper intends to clarify the trajectory patterns of migration careers in space and time. The concept of migration careers, that is, "migration in one's life history," has been widely accepted (Clark 1992). Its strict meaning is defined as "the sequence of dwellings that a household occupies from household formation to dissolution" (Davies and Pickles 1991: 629). Analysis of spatial trajectories of personal migration careers is expected to contribute to the understanding of differentiation in urban areas.

This paper analyzes and describes patterns of South African migration careers in Pretoria. The first stage of this study focuses on the fundamental elements of personal migration careers in post-apartheid Pretoria such as migration frequencies, motivations stimulating migrations, and spatial trajectories of residen- 
tial shifts. Then, the result is compared with those of Americans in Lexington, Kentucky (Tanaka 2000). The American subjects had the common characteristics of White Anglo-Saxon Protestants belonging to an upper middle or middle class. Their migration careers were characterized by extremely high mobility. As for the spatial trajectories of residential shifts within Lexington, distinctive patterns depending on preferences for place and residence were recognized. Cities of South Africa (henceforth called SA cities) are fundamentally different from cities in the United States (henceforth called US cities) in many respects. People and their lives are different between the two societies as well. After this comparison, discussion will be extended to the meanings of living places and residence choices.

South African society is the most drastically changing society in the world (Mine 1996; Thompson 1998). SA cities have been marked by clear segregation defined by political and legal systems. Prior to examining South African migration careers, SA cities are briefly reviewed with respect to the following three aspects: (1) the influence of apartheid on urban space, (2) recent urban characteristics of South Africa, and (3) the differences between cities of South Africa and of the United States.

\section{South African Cities}

\section{Segregation and apartheid}

The word "apartheid" comes from the word "apartness" in Afrikaans. ${ }^{1}$ Christopher (1983) traced the origin of apartheid cities back to the English colonial towns of Wales in the 13th century. In SA cities of the 19th century, as in the Welsh colonial towns, the dominant Whites wanted to distance themselves from other racial groups in order to avoid social friction. Although residential separation was not so clearly defined at the beginning of South Africa's colonization, segregation according to legally-defined races was later enforced to preserve a "White South Africa" through the eras of mercantilism, imperialism and apartheid (Western 1986). Davies (1981) described the history of transition from colonial cities to apartheid cities and modeled their spatial configurations.

The apartheid system was established in 1948. It affected every personal decision and action, as well as the political and economic systems of South African society. On an urban scale, apartheid was the means for the geographical manipulation of space (Lemon 1976, 1991; Western 1986). The Group Areas Act (1950) and the Black Communities Development Act (1984) were provided as racial-zoning legislation for urban areas. Thus, urban residential areas were clearly separated, and were strictly assigned to each of the population groups including Whites, Blacks, Coloureds and Asians. ${ }^{2}$ Non-White population groups were forced to live in peripheral locations. The colonial and apartheid legacy created the current housing conditions in South Africa (Goodland 1996: 1629). Although the Group Areas Act and the Black Communities Development Act were repealed in June 1991 (Christopher 1992), apartheid is still a significant influence on the urban spatial structure (Christopher 1992, 1998: 237; Robinson 1996: 219).

\section{Urban characteristics in South Africa}

During the practical withdrawal of apartheid since the 1980s in advance of the legal repeal, urban reformation in South Africa has been examined by many academic disciplines (Pickles 1992). South African geographers have tackled the academic task to seek decolonization (Crush 1993).

Urban geography in South Africa is still mostly political geography (Dewar and Pumain 1996: 604). Colonialism, apartheid and segregation are important elements in understanding urban modification in South Africa. Recent research focuses on transformation of the postapartheid cities. Four main topics can be identified, (1) the processes and patterns of residential desegregation, (2) informal settlement and urbanization, (3) land, housing, and transport in post-apartheid cities, and (4) service provision and the apartheid inheritance (Lemon 1994). Except for Christopher's (1994) study of the spatial segregation imposed by apartheid, few social area studies have been done because racial and social segregation is so prevalent. 
Today in the post-apartheid period, Blacks, Indians and Coloureds have come to occupy residences in former White neighborhoods; the White areas thus turned into 'grey' areas (Hart 1989). However, both phenomena of ethnic residential segregation and integration in urban areas are still recognized. It is important to analyze the urban residential situation in the post-apartheid period. Crankshaw and White (1995) stated that Blacks migrating into inner cities and Whites escaping from the core areas resulted in inner city decay. Even on a regional scale, the simultaneous development of Black concentration and White decentralization has clearly emerged (Geyer 1989, 1990). However, it can be said that the process of ethnic residential transition in SA cities has just begun. The high rate of female migration to urban areas is also recognized (Pick and Obrermeyer 1996). Post-apartheid South Africa is now under distorted urbanization. It might take decades to establish a different urban structure from that established during the apartheid period.

Geographical studies of Pretoria demonstrate that the former urban zoning has had a major influence on the current urban structure. Bergen and Olivier (1983) found that socioeconomic segregation among Whites is occurring only between the upper and lower classes. While some offices and firms have shifted their locations within the small central business district, some have moved from the urban center to suburban areas. Although locational shifts change the commuting patterns to work places in Pretoria, the degree of change is different between Whites and non-Whites (Prinsloo and Kersten 1983; Prinsloo 1984). According to Olivier and Booysen (1983), most Black urban residential areas and Black towns around Pretoria are far from central Pretoria, and many Blacks have to commute to relatively distant work places. The large number of such Black commuters requires a new urban traffic system and its associated public facilities. Fairhurst and Hattingh (1992/93: 120) analyzed the daily lives of working single mothers in Pretoria, and pointed out that their activities are spatially restricted because of the arrangement of urban land-use zones.

\section{Cities in South Africa and the United States}

Clear racial and ethnic segregation is commonly recognized in cities within South Africa and the United States. Despite their apparent similarities, many differences can also be seen (Saff 1995). The spatial segregation in US cities has basically formed spontaneously, while that in SA cities was determined and planned by a White government. The life styles of South African people are also quite different from those in the United States. In South Africa, individual households were legally regulated by many social and financial controls (Beavon 1982). Up to the present time, implicit and explicit restrictions on non-White population groups remain. The freedom of choice involved in American urban ecological models is not suitable for urban studies in South Africa.

In order to clarify the fundamental differences and similarities between cities in South Africa and the Unites States, intensive surveys of individual migration careers were undertaken. These surveys are expected to be useful, because they examine people's lives, urban structures, and their interrelations. In addition, this approach can contribute to the construction of general urban models.

\section{Urban Structure of Pretoria}

\section{History of urban development}

Pretoria is in the transitional zone between two plateaus (the Transvaal Highveld and the Middleveld). Geomorphologically, the city is situated in a cuesta. The many east-west trending ridges, the valleys between them, and the mountain passes have all played a decisive role in determining the urban development and transport patterns of Pretoria (Figure 1).

In 1855, Boers started construction of a new town, Pretoria, along the Apies River (Department of Development and Planning Pretoria 1984). The social and commercial center of the town was placed at Church Square. Until the discovery of gold in Witwatersrand at the end of the 19th century, Pretoria was a rural town; the discovery changed Pretoria into a regional economic center. The economic development 


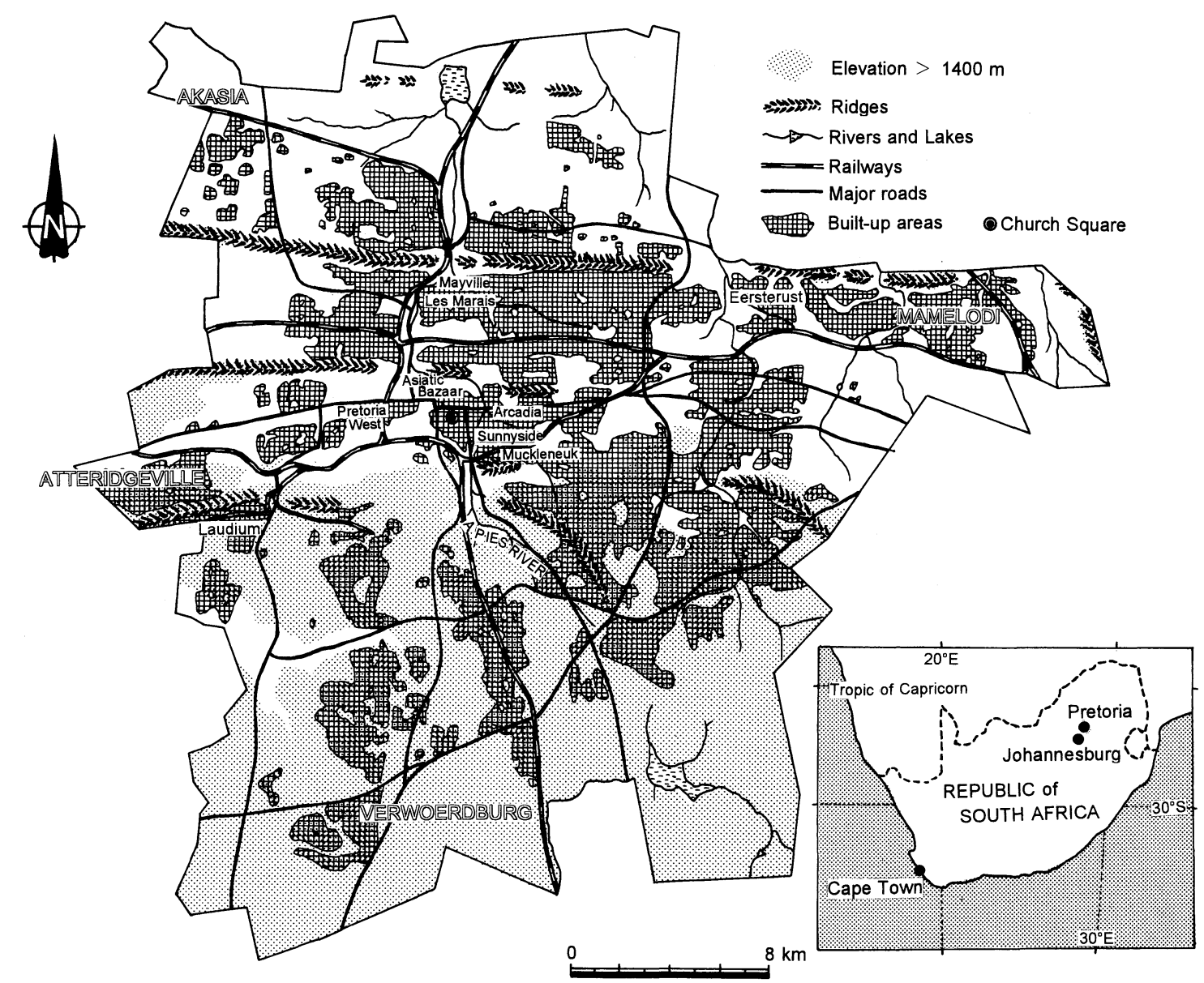

Figure 1. Pretoria, South Africa, where migration careers were studied.

stimulated administrative demands to build many governmental offices and buildings in Pretoria.

Through the 1890 s, the population of Pretoria increased. The residential areas spread to Arcadia, Sunnyside and Les Marais in 1890, then to Pretoria West, Muckleneuk, Mayville and other areas. In the original urban plan of Pretoria, no demarcation was drawn to separate the residential areas of Black people. In the decade after the Anglo-Boer War (1899-1902), the rapid expansion of the city caused establishment of many new residential areas to the northwest, north, and east of the city center.

The rapid increase in population of Pretoria in the post-World War II era required a number of new suburban residential areas. In 1949, the Atteridgeville area was purchased by the city council and was planned as a Black residential area. In 1953, a new Black township, Mamelodi, was established on the eastern fringe of Pretoria. In 1958, Eersterust and Laudium were constructed as group areas for Coloureds and Asians, respectively (Department of Development and Planning Pretoria 1984: 12). In the 1960 s and early 70 s, vast residential areas were developed, especially in the northern, northeastern, eastern and southeastern parts of the city. The speed of development decreased during the latter half of the 1970s. At present, Pretoria is not only the administrative capital of the Republic, but is also the education center of the country.

According to the 1991 national census, Pretoria has a population of 447,261 . It is composed of $67.0 \%$ Whites, $3.7 \%$ Coloureds, 3.0\% Asians, and 26.3\% Blacks. Most of the Asians are from the Indian subcontinent. Davies 


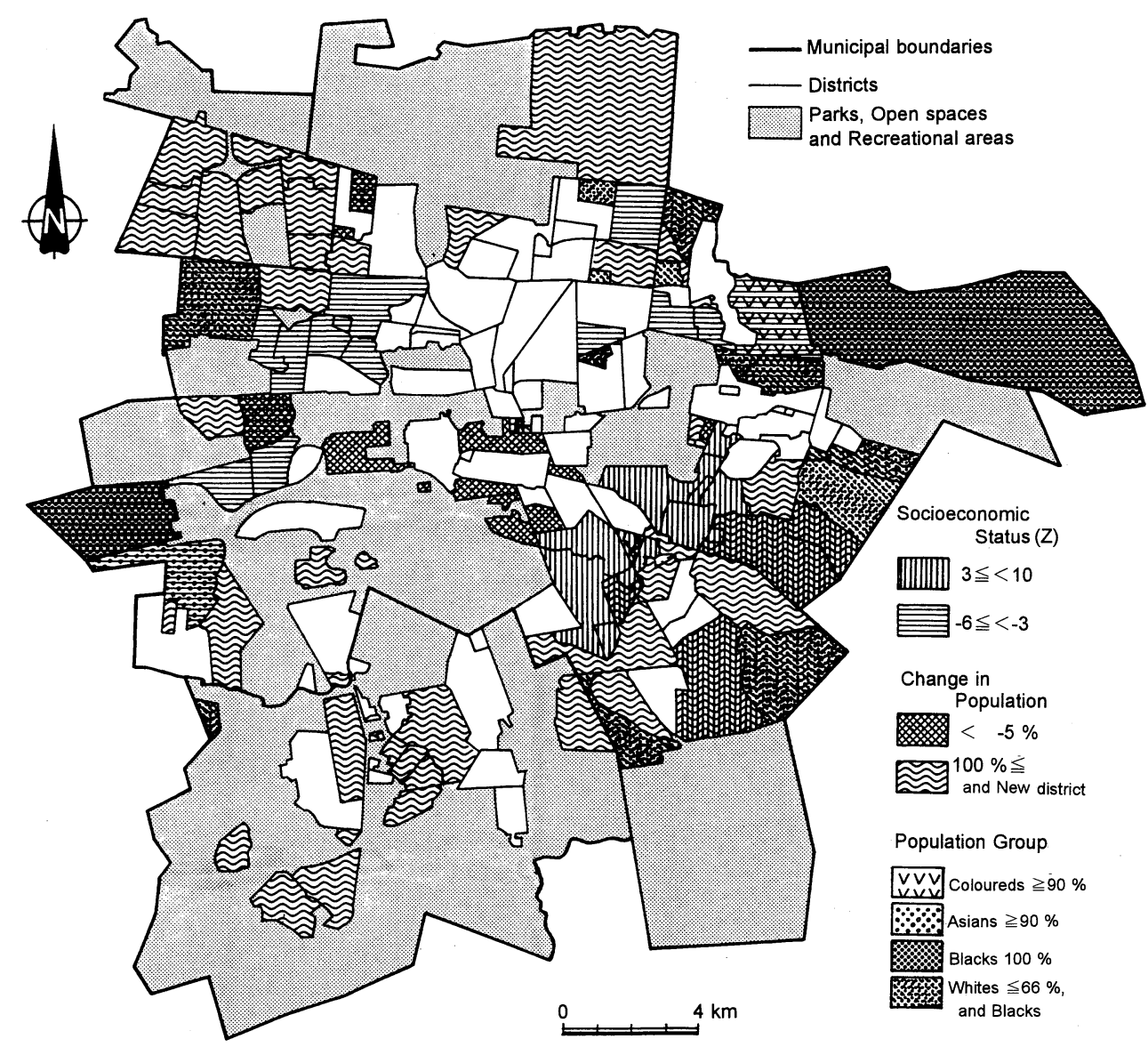

Figure 2. Socioeconomic characteristics of Pretoria's districts.

Practical index $(Z)$ for socioeconomic status used in this paper is calculated as follows: $Z=s_{1}+s_{2}+s_{3}$, where $s_{1}=\left(x_{1}-m_{1}\right) / \sigma_{1}, s_{2}=\left(x_{2}-m_{2}\right) / \sigma_{2}$, and $s_{3}=\left(x_{3}-m_{3}\right) / \sigma_{3} . x_{1}=$ percentage of high income population $(>50,000$ Rands), $x_{2}=$ percentage of highly educated population (with degree), and $x_{3}=$ percentage of population working at professional, semi-professional, technical, managerial, executive, and administrative occupations). $m$ and $\sigma$ are the mean and the standard deviation, respectively. $m_{1}=8.5, \sigma_{1}=3.3, m_{2}=11.4, \sigma_{2}=$ 8.6, $m_{3}=11.4, \sigma_{3}=8.6$. Change in population (\%) was calculated as (1991 population-1980 population)/ 1980 population. New districts were identified as districts developed after 1985, and as districts listed first in 1991 Census. Blank districts are out of discussion because of no specific characteristics about socioeconomic status. Source: Population census, Republic of South Africa (1980, 1991).

(1981) summarized the spatial transformation of Pretoria from the period of colonialism (before 1948) to that of apartheid (after 1948). During the apartheid period, non-White residential areas were located on the periphery of Pretoria. Blacks lived in Atteridgeville on the western margin and in Mamelodi on the eastern margin. Coloured people lived in Eersterust on the west side of Mamelodi, and Indians were assigned to live in Laudium on the south side of Atteridgeville. Racial segregation is clear in Pretoria, so the city is said to be a typical SA city.

Although Pretoria is a relatively safe city compared with other SA cities such as Johannesburg and Cape Town, the inner city is now decaying. One reason is that a number of Blacks in the surrounding rural regions and neighboring African countries have been illegally migrating into Pretoria. Crime also has been rapidly increasing, and many Whites have left central Pretoria. 


\section{Socioeconomic characteristics of Pretoria's districts}

Individual residential choices largely depend on the location and characteristics of the residential areas in Pretoria. Pretoria has 168 districts in its urban area, and each district is treated as a census tract. In this analysis, the 1991 and 1980 national census data are used, ${ }^{3}$ because the 1996 census had not been published in 1998 when my interview survey was conducted in Pretoria.

The following three indices were used to classify district types in Pretoria. (1) The socioeconomic status of residents. Districts of higher socioeconomic status are identified by the percentages of population with high incomes, higher education, and professional and administrative occupations. (2) Degree of segregation and integration among the four population groups. They are classified based on the composition of race and ethnicity. (3) Change in population. Districts that show rapid increases in population, or first appear in the 1991 national census, are considered to be recently developed districts.

A map of the districts classified according to the above indices is shown in Figure 2. The social and economic segregation is clear. For example, districts of lower status are located along the central axis, which stretches from eastern to western Pretoria. The lowest-status districts are found at both ends of the axis, which used to be the districts for Blacks, Coloureds, and Indians. The high-status districts are concentrated in the southeastern suburbs, which used to be the White area. Although racial segregation is still obvious, there are no districts where all residents are White. This is because wealthy White households usually have non-White domestic workers who live in their employers' houses. Racial mixing has begun in several districts of the peripheral zones. Population is decreasing in the urban center and its environs, while residential development is very active in the suburban area, especially in the southeast.

\section{Residential characteristics of Pretoria's dis- tricts}

The national census and other official statistics do not contain data about housing structure, size, price, etc. These data are necessary to analyze individual migration careers. To clarify the residential characteristics of districts, I collected data with respect to residential conditions during the middle of 1998. The data could be found in a local newspaper, the Pretoria News. The newspaper provides 'Classified' advertising supplements every weekend. Articles appearing in the 'Classified' section published at the beginning of May, June, and July 1998 were used in order to avoid counting the same information twice.

The information on the properties and residences for sale and rent was compiled along with the housing data. Of many advertisements, 968 (452 for rent and 516 for sale) indicating district location described housing types and prices; 961 (468 for rent and 493 for sale) indicating district location described the numbers of bedrooms. Although these data are not always plentiful and reliable, it is believed that they represent the present housing conditions. The data are plotted on the district map in Figure 3.

Differences in dwelling types ${ }^{4}$ among the districts are clear. Flats are concentrated in the central area. Houses are the major dwelling type in the northern and southeastern suburbs. Many town houses are located on the southeastern margin of Pretoria. Town houses are residential units built in town-house complexes. The complexes usually have security systems, and are under the builders' control even after the projects are completed. The increase in number of town-house complexes keeps pace with the increase in crime. Although townhouse sizes are generally smaller than standalone houses, their prices are not always cheaper. The southeastern suburbs of Pretoria are the most expensive residential areas, and town-house areas peripheral to the southeastern suburbs are also relatively expensive. On the other hand, flats in central Pretoria, and houses to the north, are relatively inexpensive. The variation in dwelling size basically corre- 


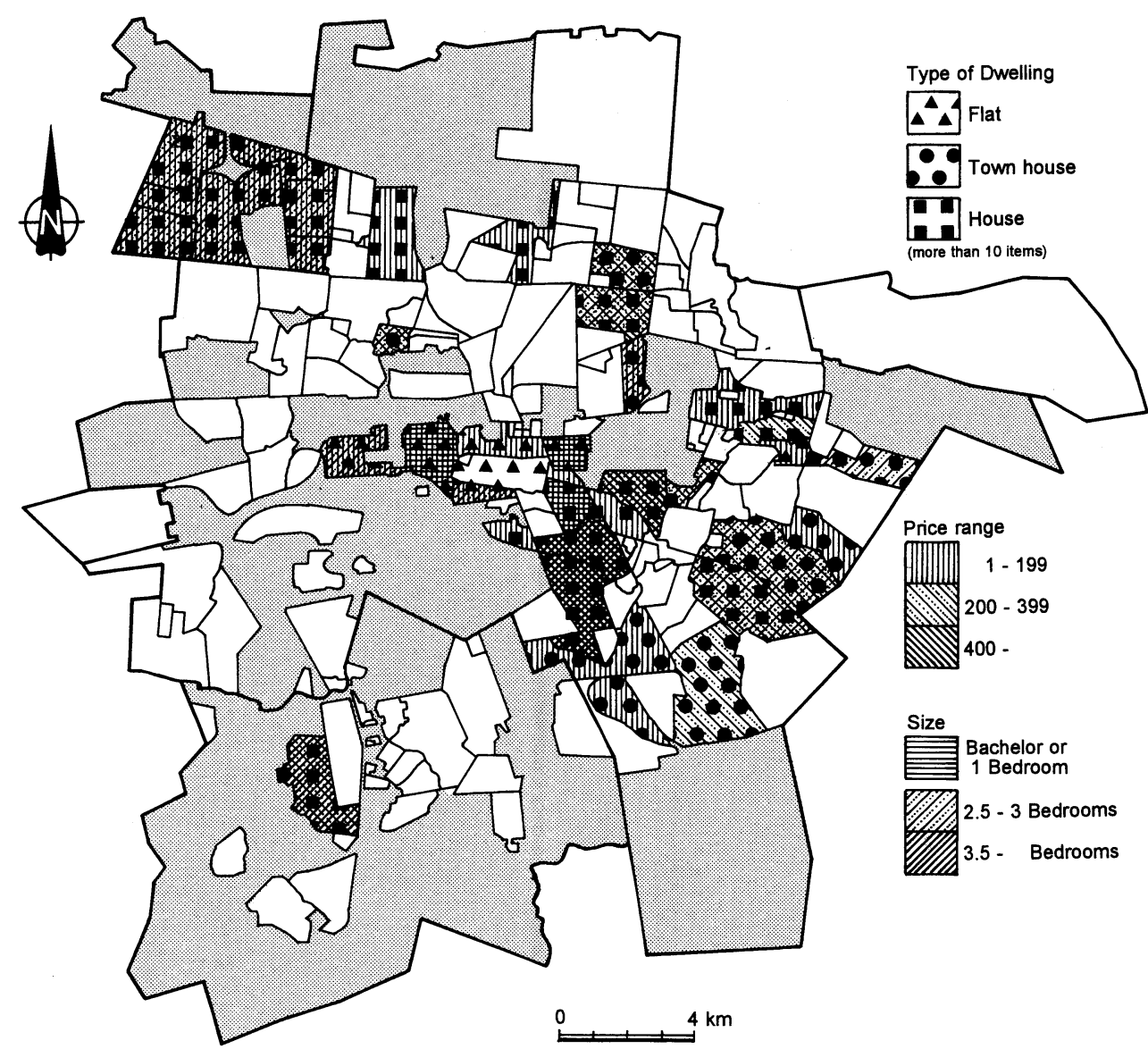

Figure 3. Residential characteristics of Pretoria's districts.

The flat type of residence includes garden flats and the town-house type of residence includes duet and cluster homes. The price ranges should be multiplied by 10 Rand for rental residences, and by 1000 Rand for residences for sale. Blank districts are out of discussion because of no specific characteristics about type, price range and size of dwellings. Source: 'Classified' section, Pretoria News, Pretoria, May 4, June 1, and July 1 (1998).

sponds to that in housing price. The best residential districts are found in the former White areas.

\section{Interview Survey of South African Migrations}

Analysis of residential shifts in urban space requires information on personal migration careers. Data for sequences of intra-urban migrations in Pretoria, at least, are necessary. Unfortunately, there are no existent surveys of individual migration careers in South Africa. The national census of the Republic provides no migration data even on a regional scale.
There is no statistical information relating to personal or intra-urban migrations in SA cities. Inevitably, the entire database of reliable and suitable information for analysis of migration careers was collected during my own interview survey. The small number of my collections means that the results deducted from this analysis may not be regarded as conclusive. However, this preliminary analysis shed the first light on migration careers in South Africa, which have been never touched upon due to various kinds of difficulties.

\section{Interview survey and subjects}

My survey was conducted in Pretoria during 


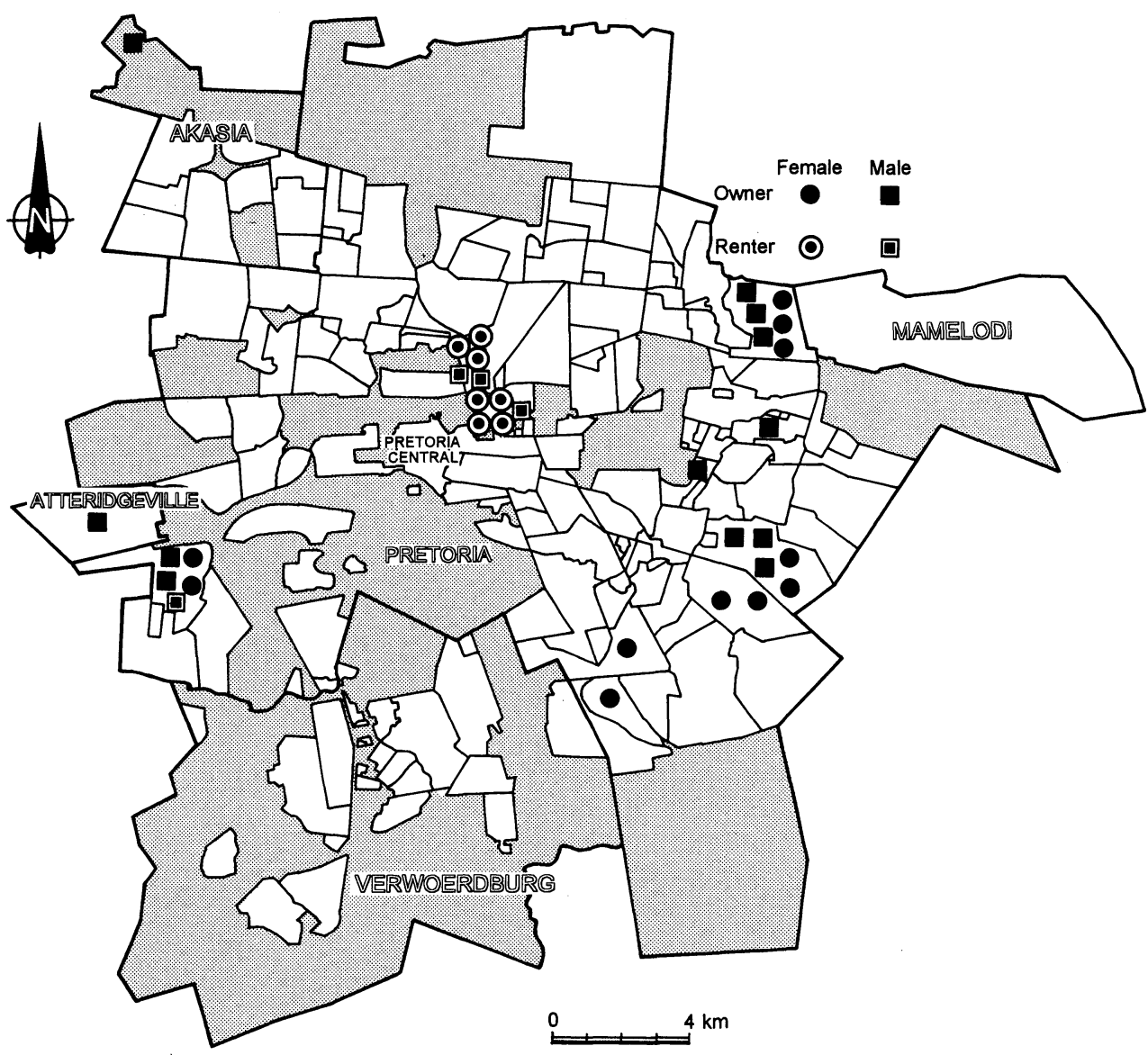

Figure 4. Distribution of the persons enumerated.

Each symbol indicates one person belonging to each category.

September of 1998. Information on migration histories was collected by face-to-face interviews with 34 subjects: 21 Whites, 6 Coloureds, 5 Indians and 2 Blacks. The White subjects are divided into two subgroups: an upper or upper middle class and a lower middle class. A university professor kindly introduced me to the subjects of the former subgroup from among his friends and neighbors. The subjects of the latter subgroup were residents living in two old-age homes in the inner city. The subjects of the Coloured group, who were introduced to me by a university clerk, were from among his numerous relatives. The Indian subjects were introduced to me by Laudium's community leader. The two Black subjects worked at Pretoria University. These subjects were, by any measure, not gathered using a statistically random sampling method, and the number of samples is very small. The numbers of samples of Whites, Coloureds, Indians and Blacks do not exactly correspond to the percentages of the four population groups. Nevertheless, the general trends of migration behavior can be tentatively determined, and they are expected to help in understanding migration careers in urban South Africa. This paper presents the first data regarding migration careers in South Africa.

Through the interviews, the retrospective data were collected. A critical and common disadvantage of the interview survey is that inaccuracy is inevitably involved in the retrospective data derived from one's own memories (Davies and Pickles 1991: 629-630). To make the data more reliable, several steps were taken: (a) a small number of questions were asked, (b) questions pertained only to migration 


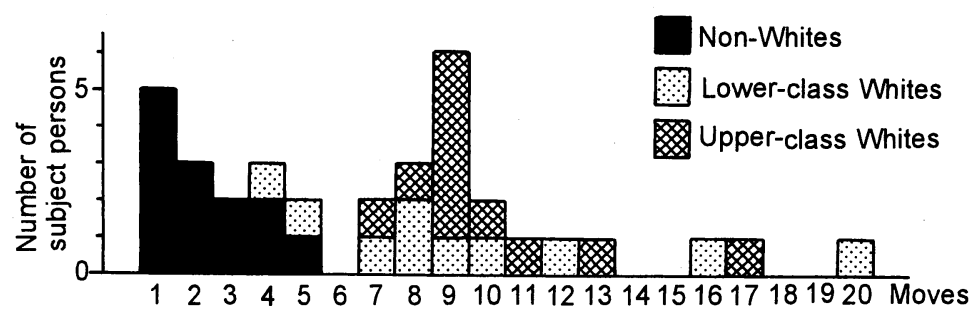

Figure 5. Migration frequencies.

sequences, and (c) the subject's privacy was carefully protected (Tanaka 1997: 20-21). In this study, the retrospective interview surveys were conducted in a scrupulous manner. Of the migrations that the subjects experienced prior to their interview, the time sequences are considered to be reliable enough to enable us to examine migration occurrences and locations.

An Indian subject and all subjects of the lower-class White subgroup are renters, and the rest own their residences. The subjects are composed of 16 males and 18 females. Locations of each subject's present residence are plotted in Figure 4 . The distribution of residences shows clear segregation: the upperclass White subgroup lives in the southeastern suburbs, the lower-class White subgroup lives in the inner city, Coloureds live in Eersterust, Indians in Laudium, and Blacks in Atteridgeville and Akasia. If residents in old-age homes have come from the same vicinity, a social segregation is recognized even among the White population as noticed by Bergen and Olivier (1983).

\section{Migration frequencies}

How often did the subjects move in their lives? This is a fundamental element of migration careers. My interview surveys in Pretoria also give this information. The sampling size (number of subjects) in my survey was relatively small for each subgroup of Coloureds, Indians and Blacks. Moreover, the non-White subjects show common features of migration behavior. Accordingly, all subjects are reclassified into three groups: upper-class Whites, lower-class Whites, and non-Whites.

The mean values of migration frequencies for each group are as follows: 10.1 moves (during 65.2 years) for upper-class Whites, 9.9 moves (during 75.6 years) for lower-class Whites, and 2.2 moves (during 59.1 years) for non-Whites (Figure 5). Although there is an age-difference of about ten years between upper- and lowerclass Whites, and the sample size is too small to discuss statistically, the following conclusions can be made: (1) non-Whites show much lower mobility than Whites. Obviously, the apartheid system has still been affecting their migration behavior. For them, the apartheid system has imposed critical restrictions not only on choices of places to live, but also on migrations within the country. Racial segregation still survives in Pretoria. In addition to the past legal urban zoning, there may be another factor to stress concerning their way of living. It is the tightness in unity of their families and the social relations in their communities. Individuals in the Coloureds and Indian groups seem to be especially bound up with their communities. A big family and a great number of relatives nearby apparently tend to make their lives more stable, comfortable, and easy. (2) The migration frequencies of Whites are high. Their mobility is slightly lower than American mobility, but much higher than German mobility (Tanaka 1994, 1997). According to the estimates of movement frequencies during one's life in developed countries made by Long (1991), White South Africans belong to a highmobility group.

\section{Motivations stimulating migration}

Two modes of migrations are identified: free and forced. It can be said that there are many aspects even about how to decide free migrations such as motivation, reason, affordability and so on. However, it is difficult to separate them in some practical migrations. In fact, the subjects of my interview gave me vague infor- 


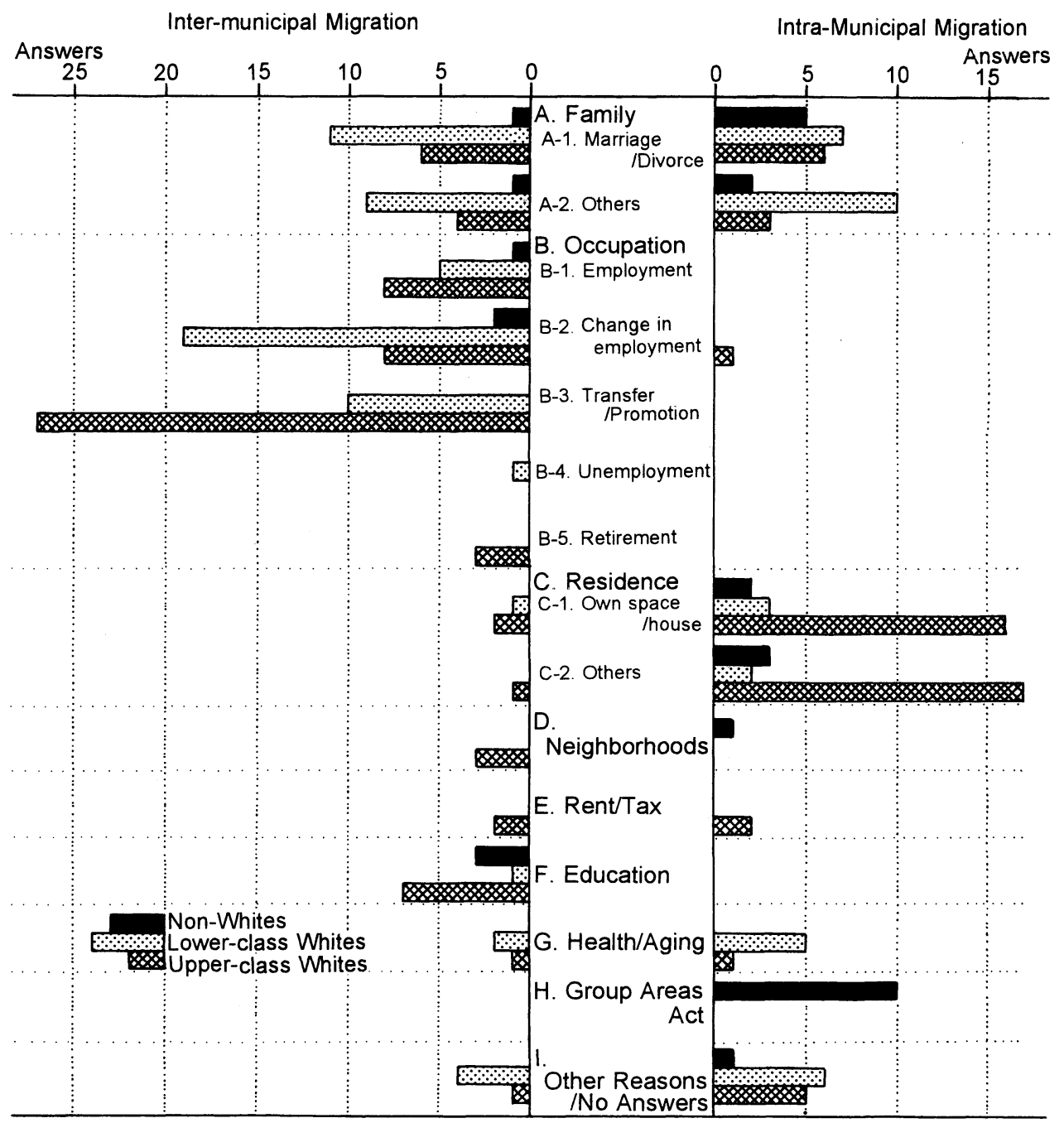

Figure 6. Motivations stimulating migration.

Implications of the terms in the central column are explained in the text.

mation about the reasons why they moved.

As for the motivations for migration, the differences among the three groups (upperclass Whites, lower-class Whites and nonWhites) are also clear, as summarized in Figure 6. With respect to Whites, the number of intermunicipal (that is, among cities, towns and villages) migrations is approximately equivalent to that of intra-municipal (that is, within individual cities, towns or villages) migrations. Generally, the motivations arising from residence problems tend to cause intra-municipal movement, while changes in occupational situations usually result in residential shifts to other municipalities. It is worth noticing that the motivations of upper-class Whites are quite different from those of lower-class Whites. White motivations for migration depend on their socioeconomic status. The motivations derived from family relations are more important for lower-class Whites. Among the motivations related to their occupation, the most important is transfer and/or promotion for upper-class Whites, while that for lowerclass Whites is a change of job. Generally, upper-class Whites move when they purchase their own residences within the same town, and move to another town to seek higher edu- 
cation. On the other hand, lower-class Whites are forced to move when evicted by landlords or when they quit their jobs because of illness.

The motivations for migration by nonWhites are considerably different from Whites. The most critical reason is the Group Areas Act, which was the legal statement of spatial segregation race by race. The second reason relates to their family. The number of intra-municipal migrations exceeds that of inter-municipal migrations. This phenomenon is caused by the strict restriction imposed on non-White population groups by the apartheid system.

Examination of South African motivations clarified the two factors most strongly affecting individual migrations: (1) the social and economic situation, and (2) political oppression by apartheid. How these factors influence the spatial trajectories of migration careers in Pretoria is analyzed in detail in the next chapter.

Additionally, it is interesting that there were no motivations relating to children in Pretoria. In the American case study (Tanaka 1995), the birth of children and their upgrowth were very important reasons for migration. Americans usually move into a slightly bigger residence when a child is born. They sometimes move to another bigger residence because of their children's growth. In South Africa, no subjects moved for such reasons. Presumably, South African residences are generally big enough to hold the increase in family members. On the other hand, Americans tend to live in a residence having the size suitable for the specific stage of family development, so if their family size changes, they will move to another residence.

\section{Migration Trajectories}

Some trajectories of the migration careers that were collected in Pretoria are shown in Figures 7, 8, and 9. Figure 2 is used as a base map for these figures, because the socioeconomic characteristics of individual districts are important when people choose their residences and places to live. In these figures, consecutive numbers indicate the sequence of residential shifts in Pretoria done by a subject, and the letter $\mathrm{B}$ indicates the place of birth. No trajectories are expressed when a subject lived in areas other than Pretoria. Accordingly, the consecutive numbers are omitted during his (her) absence. The migration occurrences in his lifetime are drawn on a migration-career graph with the horizontal axis showing age and the vertical axis showing number of moves (Tanaka 1994, 1997). Tenures (owner or renter) of residences in Pretoria are represented in the graphs if this information was ascertained.

Each of the three groups shows distinctive trajectory patterns: (1) a pattern of outward movement from the urban center to suburban areas for upper-class Whites, (2) a pattern of moving in and around the inner city for lowerclass Whites, and (3) a pattern of stability after forced movement to assigned residential areas for non-Whites. Their detailed migration histories are described in Tanaka (1999). Typical examples of the three groups are documented in the following sections.

\section{Upper-class Whites}

Three trajectories and the migration-career graphs for subjects A, B, and C are shown in Figure 7. In the following descriptions of migration histories, each subject's birthplace and numbered sequence of residential changes are indicated by $\mathrm{B}, \mathrm{M} 1, \mathrm{M} 2$, etc., respectively, in parentheses.

〈Subject A〉 is a 64-year-old man who has retired from a government office. He has lived in Pretoria two times. He came to Pretoria (M4) first with his family, because his father thought that the city would provide his children with a better opportunity for higher education. His family rented a house in the northeastern suburbs. Subsequently, they bought a house near the urban center (M5). After the subject left school he found a job on an agricultural farm outside of Pretoria, and worked there for several years. He came back to Pretoria to study at a university (M7), and rented a big flat close to his parent's home. Immediately after his graduation from the university, he took a job with the government and got married. $\mathrm{He}$ bought a house that was not far from his former flat (M8). Later, he bought a more comfortable house with a large garden $\left(2,400 \mathrm{~m}^{2}\right)$ in the east- 


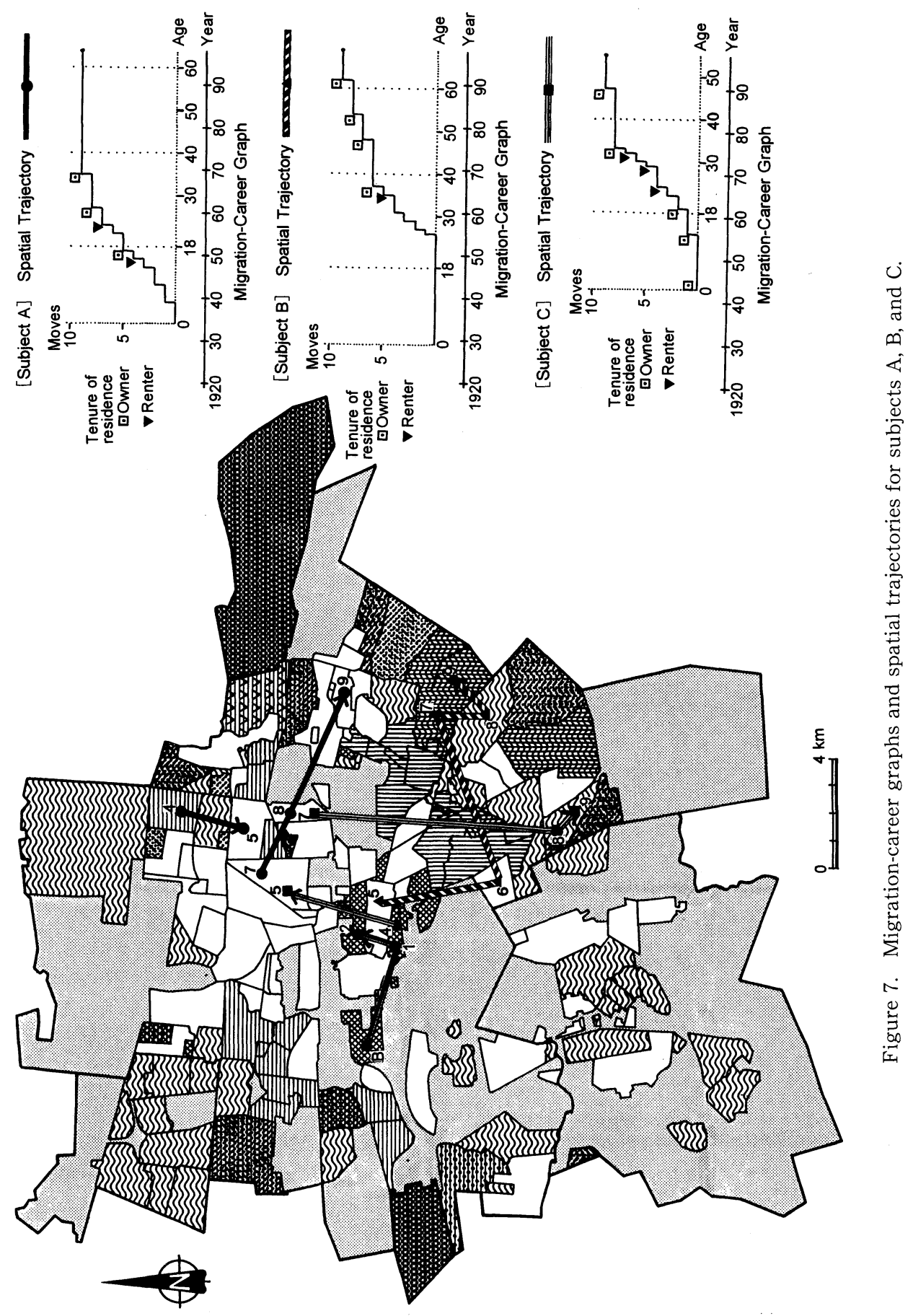




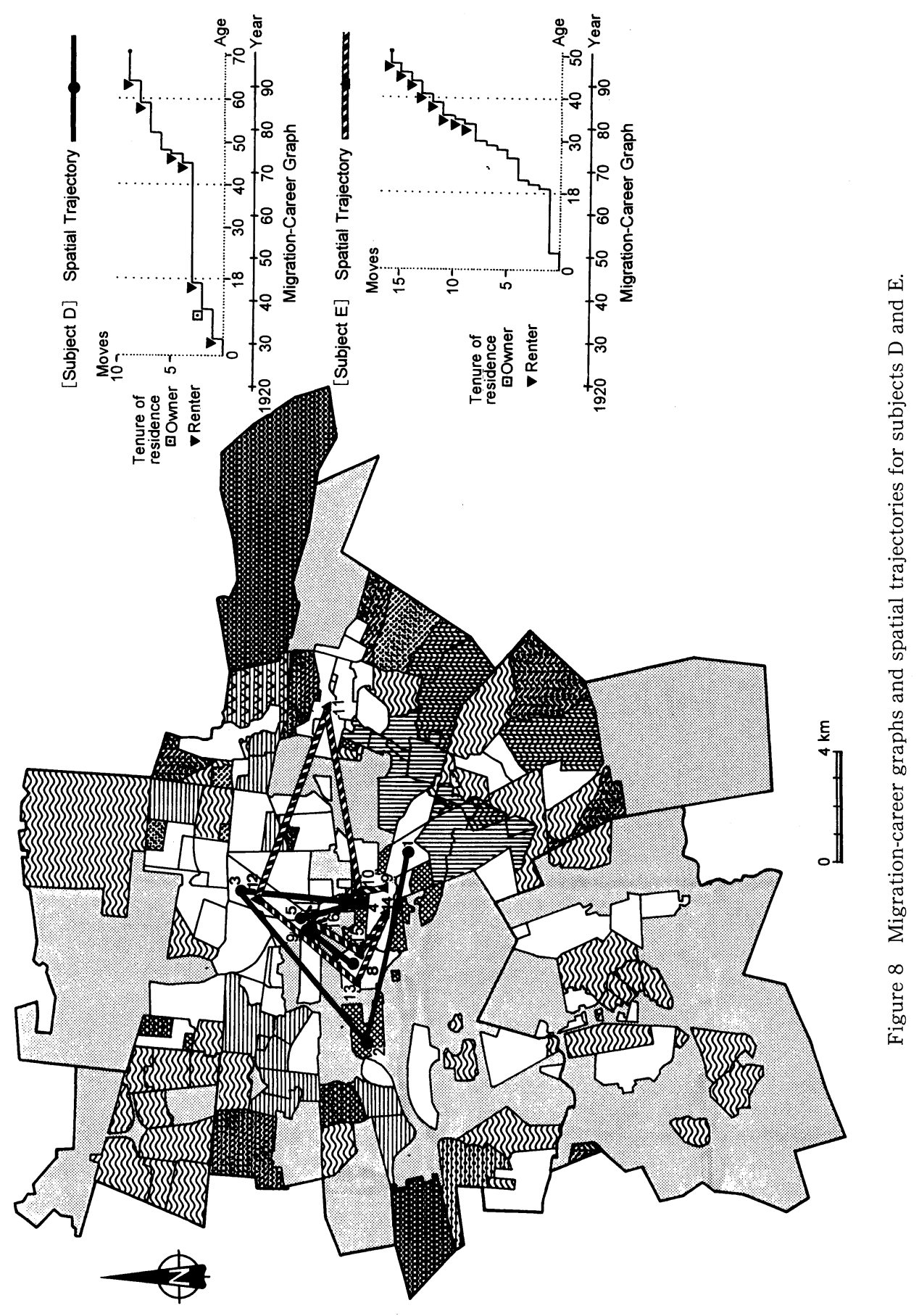




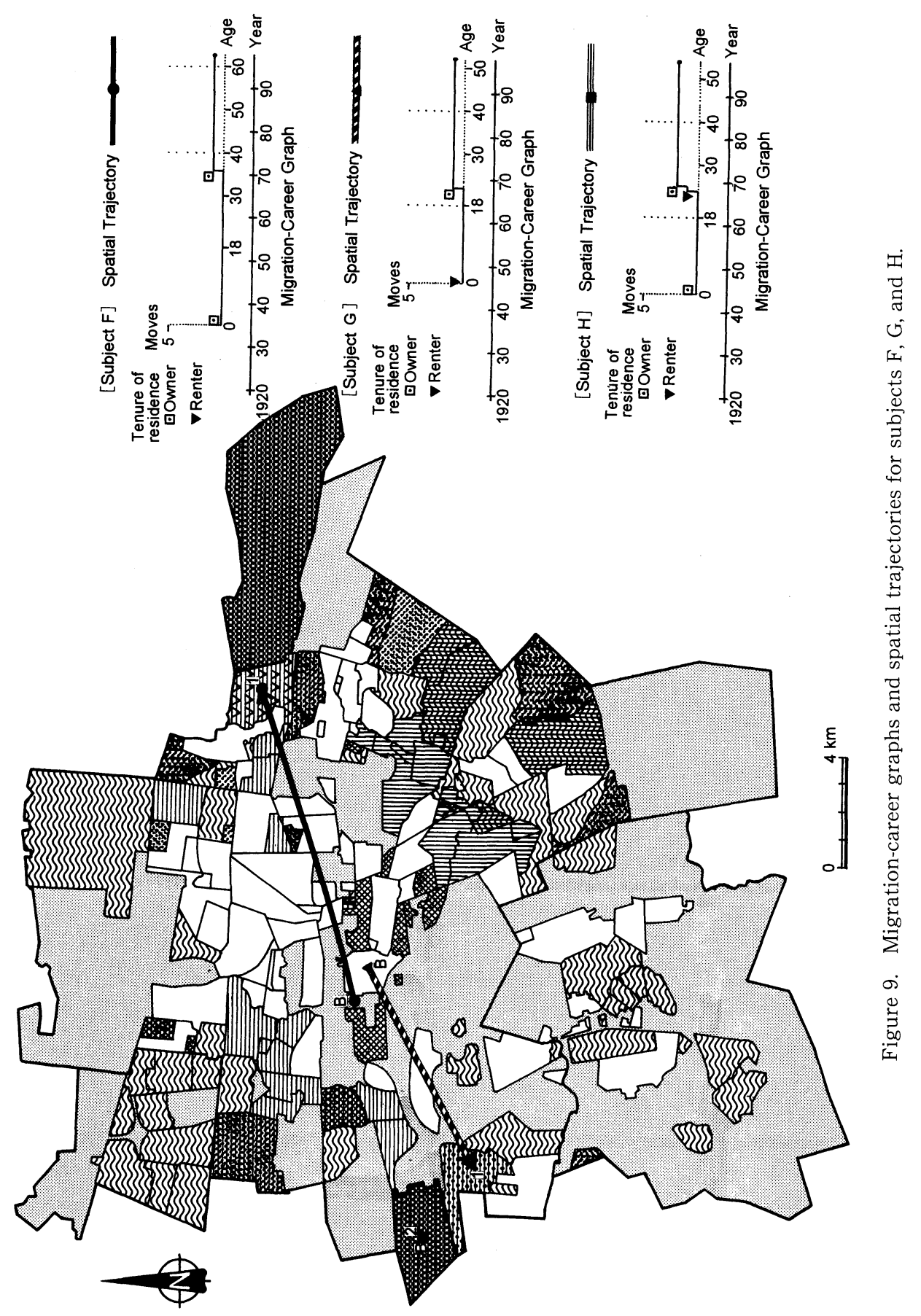


ern suburbs in which four household members lived (M9). He still lives there. Now, he is considering moving to a smaller town house, because his two children have left home and he thinks that his garden is too big for him to keep up.

During the first time he lived in Pretoria, his parents decided the family's movements and choices of new residences (M4 and M5), and he moved together with them. Since he came back to Pretoria, he himself has decided to make all migrations and choices of residences (M7, M8 and M9). As for his second time living in Pretoria, the following trends are noted: (1) the movement from the urban center outward to the eastern suburbs, and (2) the improvement of residential status in going from being a renter to an owner, and from a smaller house to a larger one.

〈Subject B is a 69-year-old housewife. In 1964 when her husband took a job in Pretoria, she moved to the city (M5). They lived with their two children in a rented flat located on the southeast side of the urban center. Two years later, they bought a brand-new house in the southern district (M6), and they lived there for eleven years. Because significant work was necessary to maintain a big garden, they moved to a town house (M7). Then, in order to realize a bigger tax reduction for the purchase of a stand-alone house, they again bought a house (M8). One year later, her husband died and her grown children left home. Upon being remarried, she bought a town house (M9). Her last three residences are located in the southeastern suburbs.

Her migration career in Pretoria is characterized by the following three trends: (1) outward movement from the urban center to the southeastern suburbs, (2) upgrade of her residential status from a renter to an owner, and (3) financial considerations related to tax payments and home maintenance.

〈Subject C〉 is a 55-year-old widow who was born in Pretoria and is now working as a secretary. She has lived in Pretoria on three different occasions. As a child, she lived in a house owned by her parents on the west side of the urban center (B). This area gradually industrialized, so her parents decided to move to a better place. They bought a house on the south side of the urban center (M1). Six years later, her father sold the house to the manager of a car garage, and bought another house on the east side of the urban center (M2). In 1965, she got married and moved to Johannesburg. Two years later, she and her husband returned to Pretoria due to his job transfer (M4). They rented a flat on the southeast side of the urban center. In 1972, they rented a house on the north side of the urban center (M5). The next year, due to her husband's transfer, they left Pretoria. In 1975, her husband was transferred back to Pretoria. They rented a house in the northeastern suburbs, and lived there with their two children (M7). Subsequently, they bought a house in the southeastern suburbs because they wanted their own house (M8). In 1989 her husband died, so she bought and moved to a smaller house in the same neighborhood (M9). Her children subsequently left home, and she now lives alone. She is planning to move in the near future. She is looking for a safe house, protected from possible intruders, in a fenced town-house complex.

The features of her migration career are summarized as follows: (1) outward movement from the inner city to the southeastern suburbs, (2) improvement of residential status from a renter to an owner after marriage, and (3) security. The last trend is the result of the present social situation in Pretoria, where the crime rate is rapidly increasing. Additionally, it should be emphasized that she was aware of inner city decay from the 1940s to 1960s. When she lived there in her parent's houses with her family during these years, the environment was much better than it is now.

\section{Lower-class Whites}

The trajectories and migration-career graphs for subjects D and E are shown in Figure 8.

$\langle$ Subject $\mathrm{D}\rangle$ is a 71-year-old male pensioner. $\mathrm{He}$ has lived in Pretoria two times. When he was four years old, his family came to Pretoria because of his father's job transfer (M1). They lived in a rented house. Subsequently, his father bought a house in which eight household members lived (M2). In 1953, subject D moved with two of his family members to an accom- 
modation provided by his company (M3). After his marriage in 1972, he lived in a rented flat with his wife. Two years later, because the flat collapsed, they moved into another rented flat (M4). Soon after the move, they divorced. In 1975, he moved to Cape Town for a number of reasons. In 1986 when he retired from work, he came back to Pretoria (M8). He rented a room in the central area for ten years. Now he lives in an old-age home (M9).

Three characteristics are noted: (1) all of his residences in Pretoria were within the inner city and its surroundings, (2) most of his residences were rented or provided, and (3) the residence size was small, partly because he lived alone most of his life

$\langle$ Subject $\mathrm{E}\rangle$ is a 52 -year-old female pensioner. The first part of her migration career was characterized by high mobility due to her unstable marital status. From the age of 34 , she lived around Pretoria continuing her high mobility. In 1981 when she took a job in Pretoria, she and her three children moved into the inner city (M9). Since then, she and her family have lived in a number of rented flats in the inner city and its surroundings (M10-15). In 1985, she left work because of a heart attack. In 1995, on the occasion of her son's marriage, she entered an old-age home (M16).

The following characteristics are noted: (1) all of her residences in Pretoria were within the inner city and its surroundings, (2) most of her residences were rented flats, and (3) most of her moves were decided by her family instead of by herself.

\section{Non-Whites: Coloureds, Indians and Blacks}

Three trajectories and their migration-career graphs for subjects $F, G$, and $H$ are shown in Figure 9.

$\langle$ Subject $\mathrm{F}\rangle$ is a 63-year-old Coloured woman and retired school teacher who is now managing a private classroom for small children. She was born in her parents' own house in Asiatic Bazaar (B). She lived there for 36 years. During these years, her parents died, she started teaching, and she got married. In 1971, she and her husband were forced to move to Eersterust, an assigned area for Coloureds according to the Group Areas Act (M1). They bought a house from the government, and have been living there with their son for 27 years. She likes to live among her many relatives and friends in the neighborhood. She has no plan to move from Eersterust.

The outstanding features of her migration career are as follows: (1) extremely low mobility, (2) movement forced by apartheid, (3) both districts where she has lived have been assigned to a specific racial group, and (4) a strong sense of belonging to her community.

$\langle$ Subject $\mathrm{G}$ 〉 is a 52-year-old Indian man who's business is housing developments. He was born in a house rented from his grandparents in the urban center (B). When he got married in 1968 , they moved to Laudium because a number of Indians were forced to move there by the Group Areas Act (M1). He bought a very small house from the government. After enlarging it twice, the house was rebuilt into a still bigger one. $\mathrm{He}$ and his large family have been living in the house for more than thirty years. Now he is constructing a new town-house complex in the district south of Laudium. The district used to be a White residential area. In the near future, he will move to a new house built in the complex. Living in a White area has been his dream for many years. Unfortunately, after the repeal of apartheid, Whites have been rapidly moving away from the district and it is becoming an Indian residential area.

His migration career is characterized by (1) stability, and (2) his deep-rooted opposition to apartheid.

〈Subject $\mathrm{H}$ 〉 is a 54-year-old Black man who is an executive officer at a university. He was born in a small house owned by his parents in Atteridgeville (B). Except for four years while he was studying at a university, he has been living in the same location. He rebuilt his house in 1982. Now five household members live in his enlarged house. In 1987, after teaching for many years, he changed his job to a managerial post in the educational department of the government. Now he and his wife are planning to move to another district in Pretoria.

His migration career is characterized by: (1) a stable migration career, (2) great attachment to his neighborhood, and (3) a growing desire, with the improvement of his economic situa- 
tion, to move from the Black residential area.

All three of these non-White subjects belong to a relatively high socioeconomic class within their population group. Although they can afford to move from their districts, and some are planning to leave, they still remain in their old neighborhoods. Two reasons are considered: one is an invisible restriction on the life styles of non-Whites, which is the legacy of apartheid. The other is that non-White people are more tightly bound to their communities. Most likely it will take one generation or two before this situation changes.

\section{Comparison with American migration careers}

By investigating American migration careers in Lexington, Kentucky, Tanaka (2000) was able to identify three typical patterns of movement among subjects belonging to the uppermiddle or middle class. First was the upgrading of residences by shifting from the central area to the suburbs, and by shifting from being a renter to an owner. Second, the residential shifts were within the subject's favorite place. Finally, there were capricious shifts of residences without any important reasons. These distinctive patterns of migration indicate that American people can move freely according to their own motivations. Of course, their migrations are possible because of economical affordability, and because of the large supply of residences in active housing markets. The important indicator is that even small cities provide a variety of residential areas and many kinds of residences from which people can choose. Spatial structures of American cities are not uniform and many types of living environments are present.

In South Africa, on the other hand, social, political, and economical conditions relating to personal migrations are quite different from those in the United States. Despite the superficial similarities in racial segregation, the processes of formation and transformation of urban structures are fundamentally different between the two countries. Apartheid and its long-lasting legacy are still visible in South African society. This situation results in the strikingly different migration trajectories among the three groups including upper-class
Whites, lower-class Whites, and non-Whites. It should be noted that human behavior and urban structure are not determined by one another, but do influence each other. People's residential choices and shifts in a city are largely influenced by the physical zoning of urban space. After the settlement pattern has been established in a city, however, the residential conditions also work to preserve the present urban structure.

\section{Conclusion}

A migration career, that is, a trajectory of personal migrations in space and time, is an important element in understanding what urban residential areas are. From this point of view, an interview survey of migration careers was conducted in Pretoria, South Africa, and the result was compared with that of a similar survey of migration careers in Lexington, Kentucky, U.S.A. Through this survey, the following findings were obtained:

(1) As for movement frequencies and motivations, there are clear differences not only between Whites and non-Whites, but also between the upper socioeconomic class and lower class of Whites. Whites are characterized by much higher mobility than non-Whites. Political oppression from apartheid has influenced personal migration behavior, because nonWhites were forced to move by the Group Areas Act. On the other hand, economical affordability is also a decision-making factor with respect to individual motivations for migrations and tenures of their residences.

(2) Each group of upper-class Whites, lowerclass Whites, and non-Whites has a distinctive pattern of trajectories. For example, while a pattern of outward movement from the urban center to suburban areas is recognized for upper-class Whites, a pattern of moving in and around the inner city is identified for lowerclass Whites. Non-Whites show an extremely stable pattern.

(3) The stable pattern of non-Whites, after forced movement into assigned residential areas, indicates that an ethnic factor exists, and it is likely that a strong sense of belonging to one's own community affects life style and 
migration.

(4) Spatial trajectories of South African migration careers are different from American trajectories, depending on the differences between their urban histories. While the US cities are basically a free society, the SA cities and society have been under political oppression from apartheid. In this sense, this finding agrees with Beavon's (1982) opinion that the freedom of choice involved in American urban ecological models is not applicable to SA cities.

Although it is obvious that much work remains to get a general conclusion about South African migration careers, this preliminary analysis seems to have taken an important step in order to clearly understand the overall patterns of migrations in South Africa.

Currently, South African society is changing drastically and rapidly. Presumably, SA cities are also changing their spatial structure, and the people's life styles are changing too. Social and racial integration have just begun. Although vestiges of apartheid remain throughout the society, both the residential structure of SA cities and personal migration behavior will change gradually, but steadily, in the coming decades.

I would like to emphasize the importance of residential differentiation in the analysis of urban structures. Why do people prefer to live in residences and places different from other people? Why have some strictly planned cities completely changed their original zoning after several decades? Studies of migration careers in urban space will likely give answers to these questions regarding fundamental urbanity and people's urban lives.

\section{Acknowledgements}

This study was financially supported by the Overseas Research Fund of the Ministry of Education, Science and Culture, Japan (No.09041062, Organizer: Prof. Dr. Shuji Funo, Department of Architecture, Kyoto University). I wish to express my sincere thanks to Professor Dr. T. Ohji, Shiga Prefectural University, Professor Dr. P. S. Hattingh and Lecturer Dr. A. C. Horn, Department of Geography, University of Pretoria, South Africa, and Professor Dr. I. Hattori, Department of Regional Environment, Fukui University, for their valuable suggestions and advice on this research. Senior Researcher Dr. J. T. Hagstrum,
United States Geological Survey, kindly improved the English of this manuscript.

(Received Jun. 20, 2000)

(Accepted Oct. 7, 2000)

\section{Notes}

1. Afrikaans is a language modified from the 17th-century Dutch. It is one of the official languages of the Republic of South Africa.

2. The entire population was classified into discrete groups under the Population Registration Act passed in 1950 (Christopher 1998: 225). Four groups were adopted: (1) Whites are people of European origin, but excluding those of mixed origin. Whites are composed of two distinctive subgroups: the Afrikaners, descended from the original Dutch settlers who first came in 1652; and the English-speaking subgroup, whose main settlements were from 1820 on. (2) Africans (Blacks) are people indigenous to Africa, south of the Sahara, but excluding the Khoisan populations. The majority Black people speak Bantu languages. (3) Coloureds, all other people. The Dutch brought slaves mainly from the Dutch East Indies and partly from Madagascar, and these mingled with the Khoikhoi (Hottentots); there was also a strong admixture of white genes. In consequence this group was highly diverse in origins and background. (4) Asians are people of Asian origin, mainly Indians, with the exception of the descendants of slaves imported by the Dutch in the seventeenth and eighteenth centuries (Cape Malays). Most of them speak English and their own Indian languages as well (Christopher 1998: 225; The Encyclopedia Americana 1994: 265-266 (vol. 25)).

3. Data from Central Statistical Service 1991, Population Census 1991: Selected statistical region Pretoria/Wonderboom/Soshanguve, Republic of South Africa. Additional data were from Population Census 1980.

4. There are special housing terms peculiar to South Africa. According to Prof. P.S. Hattingh, University of Pretoria, they are as follows;

(1) Duet: Duplex in American English. This is a semi-detached house, that is, a part of a building divided into two self-contained residences.

(2) Cluster home: a residential building which has many independent units just like an apartment building. The units are rented or owned. (3) Town house: a separated or semi-detached house built in a housing complex developed by a constructor. The size of town-houses and the properties belonging to each of them are relatively smaller than those of separated-type houses in private properties. A complex is composed of fairly densely disposed town 
houses. A constructor sells town houses to buyers, and usually continues to maintain the town-house complex after sale.

(4) Garden flat: a small apartment built in a private garden. Some garden flats attach to their main houses, and others are separated. Usually a garden flat is called "a granny flat."

\section{References}

Beavon, K. S. O. 1982. Black townships in South Africa: Terra incognita for urban geographers. South African Geographical Journal 64: 3-20.

Bergen, M. M., and Olivier, J. J. 1983. Sosiale Differensiasie tussen Blanke etniese Groepe in Pretoria. (Social differentiation amongst White ethnic groups in Pretoria) South African Geographer 11: 41-48. (Afrikaans with English summary)

Christopher, A. J. 1983. From Flint to Soweto: Reflections on the colonial origins of the apartheid city. Area 15: 145-149.

Christopher, A.J. 1992. The final phase of urban Apartheid zoning in South Africa, 1990/1. South African Geographical Journal 74: 29-34.

Christopher, A. J. 1994. The atlas of Apartheid. London: Routledge.

Christoper, A. J. 1998. (De)segregation and (dis) integration in South African metropolises. In Urban segregation and the welfare state: Inequality and exclusion in western cities, ed. S. Musterd and W. Ostendorf, 223-237. London: Routledge.

Clark, W. A. V. 1992. Comparing cross-sectional and longitudinal analyses of residential mobility and migration. Environment and Planning $A$ 24: 1291-1302.

Crankshaw, O., and White, C. 1995. Racial desegregation and inner city decay in Johannesburg. International Journal of Urban and Regional Research 19: 622-638.

Crush, J. 1993. The discomforts of distance: Postcolonialism and South African geography. South African Geographical Journal 75: 60-68.

Davies, R. J. 1981. Spatial formation of the South African city. Geojournal Supplementary Issue 2: 59-72.

Davies, R. B., and Pickles, A. R. 1991. An analysis of housing careers in Cardiff. Environment and Planning A 23: 629-650.

Department of Development and Planning Pretoria. 1984. Greater Pretoria guide plan 1984. Pretoria: Pretoria.

Dewar, N., and Pumain, D. 1996. Doing urban geography in South Africa. Environment and Planning $A$ 28: 603-605.

Fairhurst, U. J., and Hattingh, P. S. 1992/93. Timespace and everyday life: South African mothers in urban context. South African Geographer 20: $116-127$.
Geyer, H. S. 1989. Differential urbanization in South Africa and its consequences for spatial development policy. African Urban Quarterly 4: 276-291.

Geyer, H.S. 1990. Implications of differential urbanization on deconcentration in the PretoriaWitwatersrand-Vaal triangle metropolitan area, South Africa. Geoforum 21: 385-396.

Goodland, R. 1996. The housing challenge in South Africa. Urban Studies 33: 1629-1645.

Hart, G. 1989. On grey areas. South African Geographical Journal 71: 81-88.

Knox, P. 1987. Urban social geography: An introduction. 2nd ed. Harlow: Longman.

Lemon, A. 1976. Apartheid: A geography of separation. Farnborough: Saxon House.

Lemon, A. 1991. Homes apart. Bloomington: Indiana University Press.

Lemon, A. ed. 1994. The geography of change in South Africa. London: Belheaven.

Long, L. 1991. Residential mobility differences among developed countries. International Regional Science Review 14: 133-147.

Mine, Y. 1996. Minami-afurika: 'Niji no kuni' heno ayumi (South Africa). Tokyo: Iwanami-shoten. (J)

Olivier, J. J., and Booysen, J. J. 1983. Some impacts of Black commuting on Pretoria. South A frican Geographical Journal 65: 124-134.

Pick, W. M., and Obrermeyer, C. M. 1996. Urbanization, household composition and the reproductive health of women in a South African city. Social Science and Medicine 43: 1431-1441.

Pickles, J. 1992. Writing futures, rewriting pasts. Urbanization in post-Apartheid South Africa: A review essay. Environment and Planning A 24: 417-440.

Prinsloo, D. A.1984. Mobiliteit van Kantoorondernemings binne die Sentrale Sakegebied van Pretoria. (Mobility of office firms in the central business district of Pretoria) South African Geographer 12: 109-122. (Afrikaans with English summary)

Prinsloo, D. A., and Kersten, S. E. 1983. Journey to work patterns and office decentralization in Pretoria: A case study. South African Geographer 11: 115-125.

Robinson, J. 1996. The power of apartheid: State, power and space in South African cities. Oxford: Butterworth-Heinemann.

Saff, G. 1995. Residential segregation in postapartheid South Africa: What can be learned from the United States experience. Urban Affairs Review 30: $782-808$.

Tanaka. K. 1994. An analysis of American migration careers. Human Geography 46: 474-495. (JE)

Tanaka, K. 1995. A case study of American migration careers. Memoirs of the Faculty of Education, Fukui University III-49: 65-121. (JE)

Tanaka, K. 1997. An analysis of German migration careers: A case study in Cologne, Germany. Memoirs of the Faculty of Education, Fukui Univer- 
sity III-53: 15-37.

Tanaka, K. 1999. Jukyo-ido kara mita Pretoria no toshi-kozo (South African residential shifts and the urban structure of Pretoria). In The overseas research report on comparative study of formation and domestication of colonial cities, ed. S. Funo, 3/ 169-3/192. Kyoto: Department of Architecture, Kyoto University. (J)

Tanaka, K. 2000. Toshi kukan bunseki (Urban spatial analysis). Tokyo: Kokon-shoin. (J)
Thompson, L. 1995. A History of South Africa, Revised edition. New Haven: Yale University Press. Translated by Miyamoto, M., Yoshikuni, T., and Mine, Y. 1998. Shinpan minami afurika no rekishi. Tokyo: Akashi Shoten. (J)

Western, J. 1986. South African cities: A social geography. Journal of Geography 85: 249-255.

$(\mathrm{J})$ : written in Japanese

(JE): written in Japanese with English abstract 